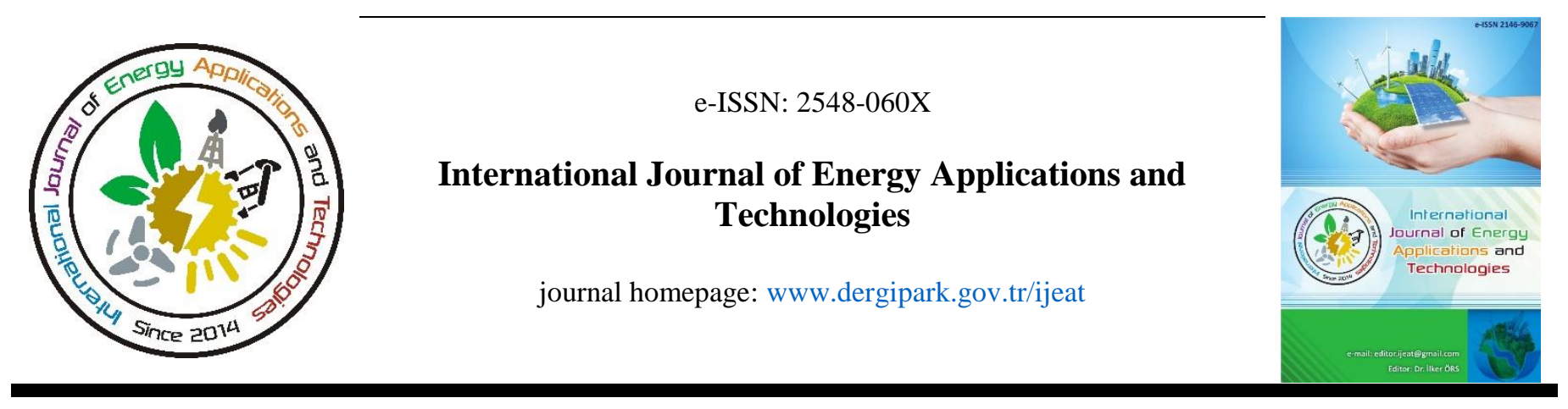

Review Article

\title{
Using alternative energy in aircraft
}

\author{
Rüştü Güntürkün ${ }^{1}$, Servet Çınar ${ }^{2}$ \\ ${ }^{I}$ Selcuk University School of Civil Aviation, Department of Aviation Electrical and Electronic, Konya, Türkiye \\ ${ }^{2}$ Selçuk University School of Civil Aviation, Graduate Student, Konya, Türkiye
}

\begin{abstract}
ARTICLE INFO
* Corresponding author

rustu.gunturkun@selcuk.edu.tr

Received December 7, 2021

Accepted December 23, 2021

Published by Editorial Board Members of IJEAT

(C) This article is distributed by Turk Journal Park System under the CC 4.0 terms and conditions.
\end{abstract}

doi: 10.31593/ijeat.1033611

\begin{abstract}
In this study, solar powered airplanes and hybrid electric airplanes are examined. Today, with the depletion of fossil fuels and their harmful effects on the environment becoming visible, it has become necessary to use alternative energy more in every field. Solar energy has become one of the most used renewable energy sources as a result of achieving the desired level of performance with the developing technology. As a result, the construction of airplanes flying with solar energy has been accelerated. Battery-powered airplanes have the lowest $\mathrm{CO}_{2}$ emissions and environmental benefits. Continuous improvement of aircraft fuel efficiency plays a crucial role in the work towards the carbon reduction target. Solar powered airplanes produce neither $\mathrm{CO}_{2}$ nor polluting emissions that affect air quality. Their noise generation is much lower than that of aircraft powered by internal combustion engines. Hybrid-electric aircraft are seen as a very effective alternative to conventional short- and medium-range aircraft in the near future. The biggest advantage of solar powered flights, and the main purpose of developing them, is that they depend on a clean form of energy with zero harm to the environment. Solar energy is a clean, free and renewable energy source, which gives it a great advantage over fossil fuels. It is a fact that the use of solar energy, which is an alternative energy, in aircraft is very important in reducing fossil fuels as a result of both a clean nature and reducing aircraft engine noise.
\end{abstract}

Keywords: Alternative energy, $\mathrm{CO}_{2}$ Emission, Electric aircraft, Solar energy, Hybrid-Electric Aircraft

\section{Introduction}

In the last 50 years, the increase in the efficiency of solar cells and their very thin design have ensured that electricity and sun rays can enter every area where they exist. Solar cells are named according to the material used in their construction and there are many types. Efficiency varies from 5\% to $43 \%$ according to the material used. However, solar cells with $5 \%$ to $20 \%$ efficiency are used in the market in terms of cost. Due to the oil crises and price increases in the world in the 19741978 period, solar energy studies have accelerated and have survived to the present day [1]. The energy need in the world is increasing by about 5\% every year and the fossil fuel reserves are decreasing rapidly. According to the most optimistic forecasts, oil reserves will be depleted in the next
50 years, natural gas reserves in 67 years and coal reserves in 235 years [2]. Accordingly, the social cost (cost spent on harmful effects such as natural disasters and diseases) of a fossil fuel-based power plant is $0.27 \$ / \mathrm{kWh}, 0.01 \$ / \mathrm{kWh}$ for a wind farm and almost zero for a solar power plant [3]. About $1.5 \times 108 \mathrm{~km}$ from Earth. It takes about 8.33 minutes for the rays of the sun, which is at a distance, to come to earth [4]. Considering that a planar collector with an area of $100 \mathrm{~m}^{2}$ works with $40 \%$ efficiency, depending on time and climate, it has been calculated that approximately $180 \mathrm{kWh}$ of energy can be obtained in one day, which is equivalent to a human weight of hard coal [5]. While the current rate is $33 \%$, it is estimated to decrease to $30 \%$ in 2010 and $26 \%$ in 2020[6]. The PV system of solar energy can directly convert solar radiation energy into electrical energy [7]. The electricity 
need for electrical devices to work at home is met by solar panels installed on the roof [8]. Since the electrical energy to run the system is taken from the sun, it contributes to minimizing the increasing electricity costs and protecting nature by reducing air pollution [9].

Plans to use electricity as a clean propulsion for airplanes have made strong progress recently. Electric motors do not produce any emissions during their operation, making them a crucial element of technology in meeting the 2050 environmental target. Electric power generation is clearly not emission-free today, but the associated emissions are expected to decrease significantly [10]. Fully battery electric airplanes do not produce any exhaust emissions, with hybrid airplanes significantly lower than those with combustion engines. This is an important benefit for local air quality around airports [11]. Moreover, besides smart home control system, electrical demand of the house has been supplied from solar energy in this study. For that aim, two solar panels have been placed on the roof of the prototype house and electricity cost which is increasing day by day has been reduced [12].

\section{Solar Aircraft}

\subsection{Advantages of solar aircraft}

The biggest advantage of solar powered flights, and the main purpose of developing them, is that they depend on a clean form of energy with zero harm to the environment. Solar energy is a clean, free and renewable energy source, which gives it a huge advantage over fossil fuels.

\subsection{Disadvantages of solar aircraft}

While this applies to all types of aircraft, weather changes affect conventional flights less than solar-powered flights. While the weather can delay the schedule of conventional airplanes or make flying a more difficult task, solar powered airplanes cannot fly except in certain weather conditions, especially long-haul flights because they need to be recharged while charging.

\subsection{Expensive equipment}

While the energy source itself is essentially free, the equipment and technologies required to harness and use solar power are extremely expensive given the scale required to fly single-seat airplanes, let alone commercial airplanes [9].

\section{The First Solar-Powered Airplanes}

\subsection{Mauro solar riser}

Although the Mauro Solar Riser is the first manned aircraft to fly with the sun, it is not the first solar-powered aircraft to fly in history. On November 4, 1974, AstroFlight Sunrise took off unmanned from Bicycle Lake in California, successfully completing 27 flights of the first prototype.

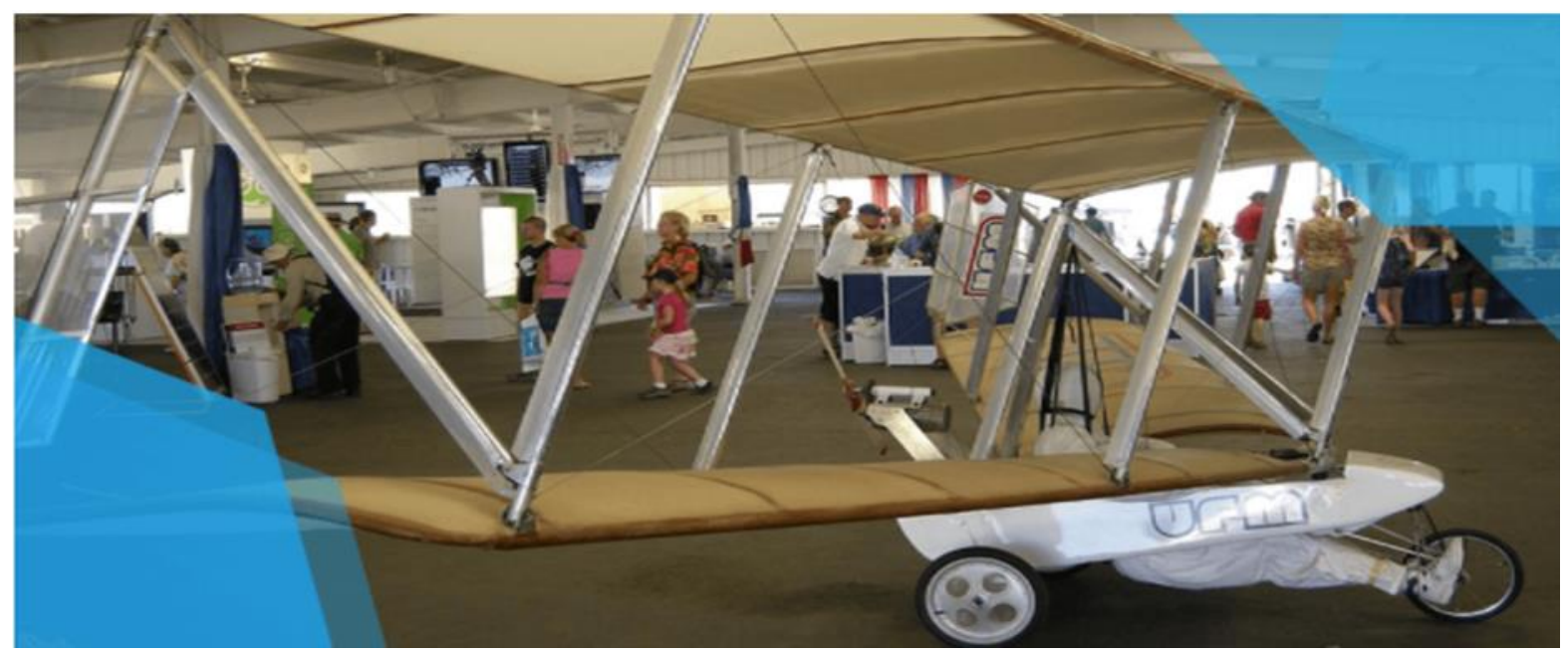

Fig. 1. Mauro solar riser [14]

Four years later, on April 29, 1979, the Mauro Solar Riser, led by its eponymous designer Larry Mauro, became the first manned solar aircraft to take off from Flabob Airport in Riverside, California. The aircraft was powered by a $3.5 \mathrm{hp}$ Bosch motor connected to a $30 \mathrm{~V}$ nickel-cadmium battery pack charged by an array of photovoltaic solar panels mounted on its upper wing to provide 350 Watts. Solar Riser, manufactured by Ultralight Flying Machines, could fly between 3 and 5 minutes after charging its cells for 1.5 hours, and the speed of the aircraft could reach up to 32 kilometers per hour [14].

\section{Solar Impulse Planes}

\subsection{Solar impulse 1}

Recently, the need for clean energy has become very important. The Swiss project, known as Solar Impulse, was started in 2003 by Swiss engineer André Borschberg and balloonist Bertrand Piccard. The aim of the program was to 
develop a single-seat, fixed-wing, solar-powered aircraft capable of circumnavigating the globe [15]. Solar Impulse 1 completed its first test flight in December 2009, covering a distance of 350 meters at an altitude of about 1 meter from the ground. The real test for Solar Impulse 1 is in April 2010, when Marcus Scherdel piloted 87 minutes at an altitude of 1,200 feet.

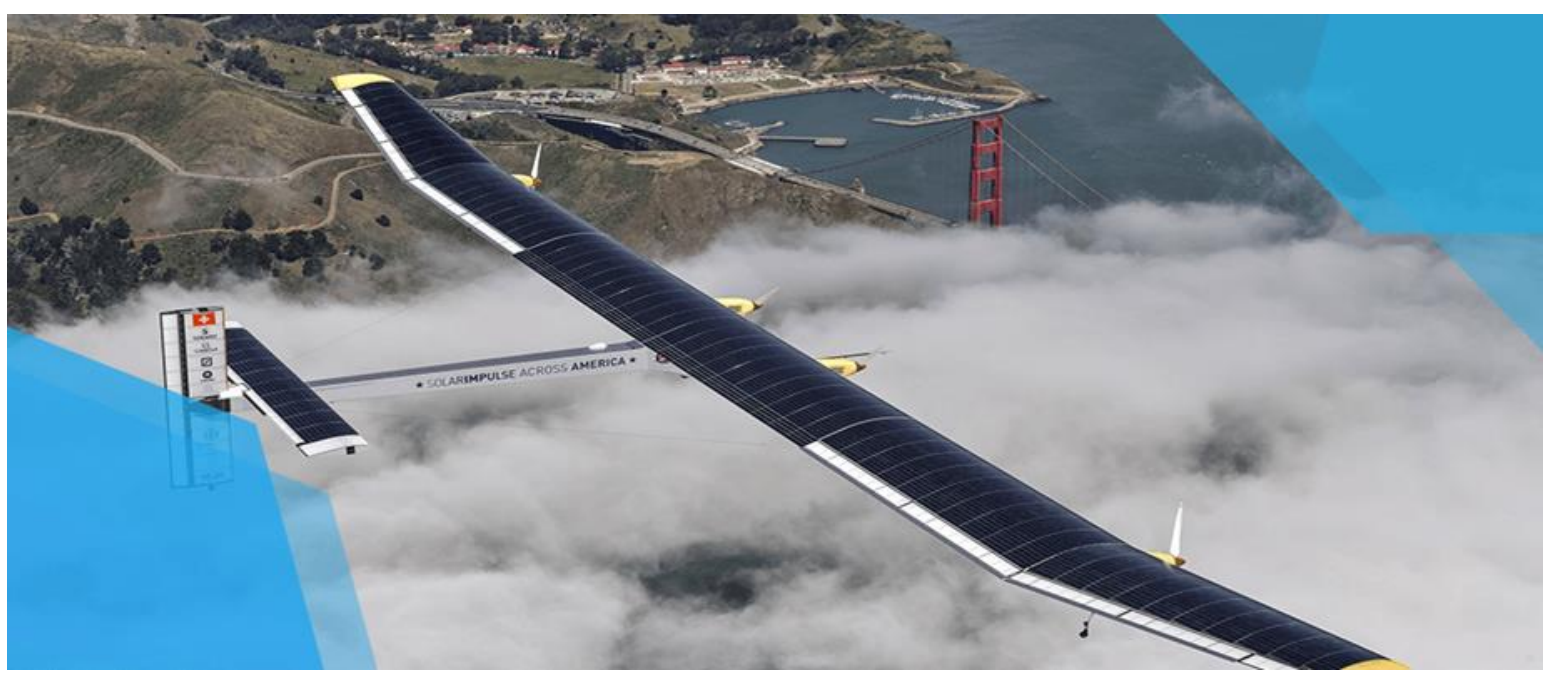

Fig. 2. Solar impulse 1

\subsection{Solar impulse 2}

The best solar-powered airplane ever built was developed at the Federal Technical University in Lausanne. The aircraft, called Solar Impulse 2, was designed by B. Piccard and A.
Borschberg. Solar Impulse 2 is the second model developed for the project after Solar Impulse 1, which continues to fly at night by storing energy during the day through lithium ion batteries.

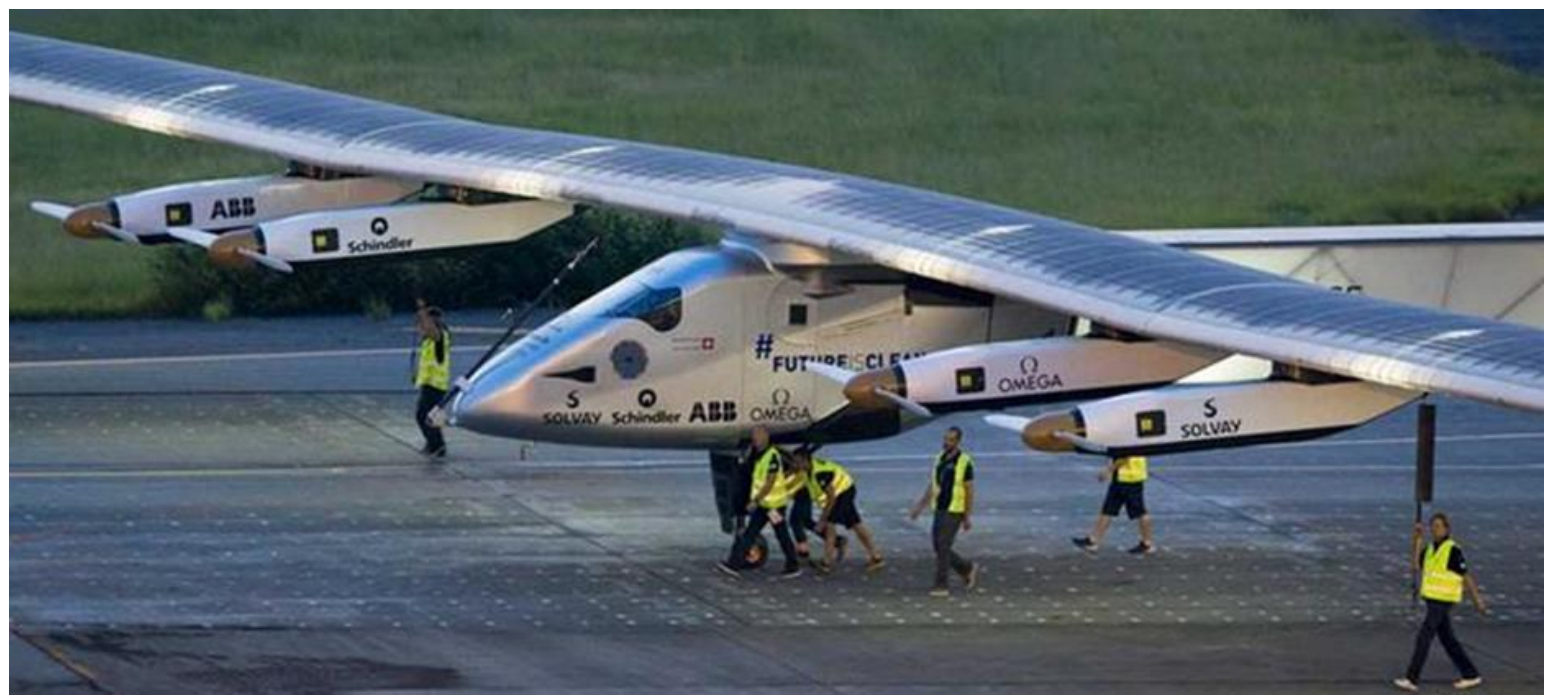

Fig. 3. Solar impulse 2

Solar Impulse 2 had many advanced technologies and features that its predecessors did not have, such as the autopilot system and oxygen mask, allowing the aircraft to fly at an altitude of up to 12,000 feet. Performance characteristics, the aircraft has a maximum speed of 140 kilometers per hour. This is made possible by the upgraded power plant consisting of four electric motors connected to four lithium-ion batteries charged by 17248 solar cells installed on the aircraft's 72-meter-long wing. The first takeoff of Solar Impulse 2 took place in 2014, reaching an altitude of 1,700 meters and traveling at an average ground speed of 56 kilometers per hour. Solar Impulse 2 successfully made both its first night flight and its first flight at maximum altitude [15].

\subsection{Future of solar impulse}

In 2016, the program announced its plans to develop a third Solar Impulse airplane that would be able to accomplish some of the tasks usually done by satellites. It is still unclear when we should expect to see the new prototype [9]. 


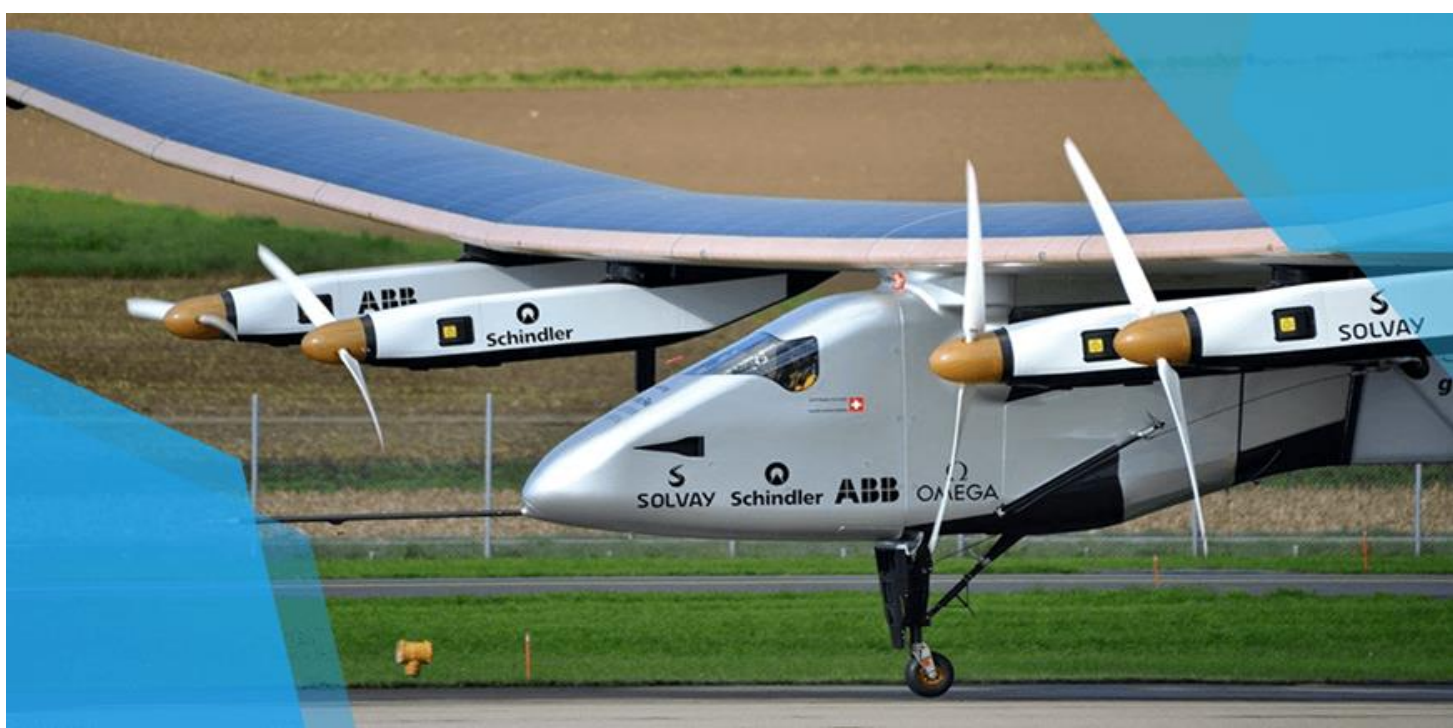

Fig. 4. Future of solar impulse aircraft

\section{Solar-Powered Airplanes Developed by NASA}

\subsection{Pathfinder plus solar powered aircraft}

The Pathfinder solar-powered aircraft was designed and fabricated by AeroVironment in the early 1980's to support a classified program. After its initial flight series, it was determined that the technology required had not reached a level where ultra-long duration flight (many days) under solar power could be achieved. At that point the aircraft was placed in storage. In 1993, the aircraft was brought back to flight status by the Ballistic Missile Defense Organization and in 1994, transferred to NASA to develop science platform aircraft technology as part of the NASA's Environmental Research Aircraft and Sensor Technology (ERAST) Program. A series of flights were planned to demonstrate that an extremely light and fragile aircraft structure with a very high aspect ratio (the ratio between the wingspan and the wing chord) can successfully take-off and land from an airport and can be flown to extremely high altitudes (between 50,000 and 80,000 feet) propelled by the power of the sun [16].

\subsection{Helios type solar powered aircraft}

He then developed a second solar-powered drone, named Helios, and flew in 1999. Helios had a wingspan of 75 meters and was longer than the jumbo jet Boeing-747. The aircraft, which has 14 engines, broke a record in 2001 by climbing to an altitude of 29.5 kilometers. Made of styrofoam (foam), carbon fiber, epoxy resin, and kevlar, the plane was very light. While flying over Hawaii, it fell into the ocean and disintegrated in 2003[17].

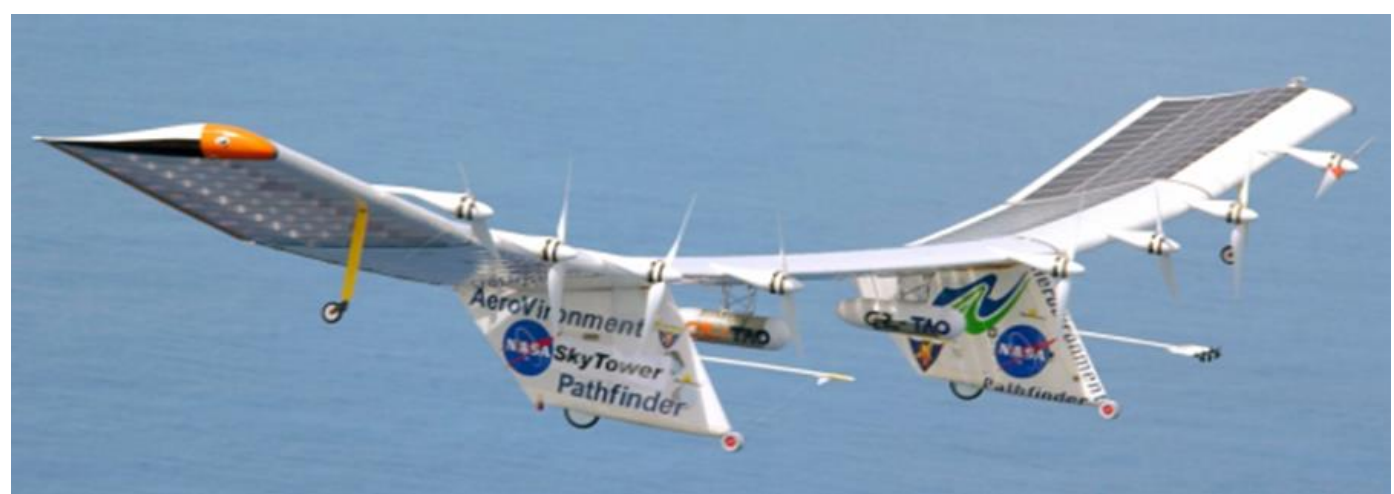

Fig. 5. NASA's pathfinder solar aircraft

\section{Hybrid-Electric Aircraft}

Hybrid-electric aircraft are seen as a very effective alternative to conventional short- and medium-range aircraft in the near future. Many large companies in the aerospace and electrical equipment industries are investing in this technology, such as Airbus, Siemens, Rolls-Royce, Boeing and others. These aircraft are designed to replace conventional aircraft powered by combustion engines on regional routes. According to DLR studies, it will be entirely possible to replace $60 \%$ to $70 \%$ of all conventional regional aircraft with hybrid aircraft [18]. 


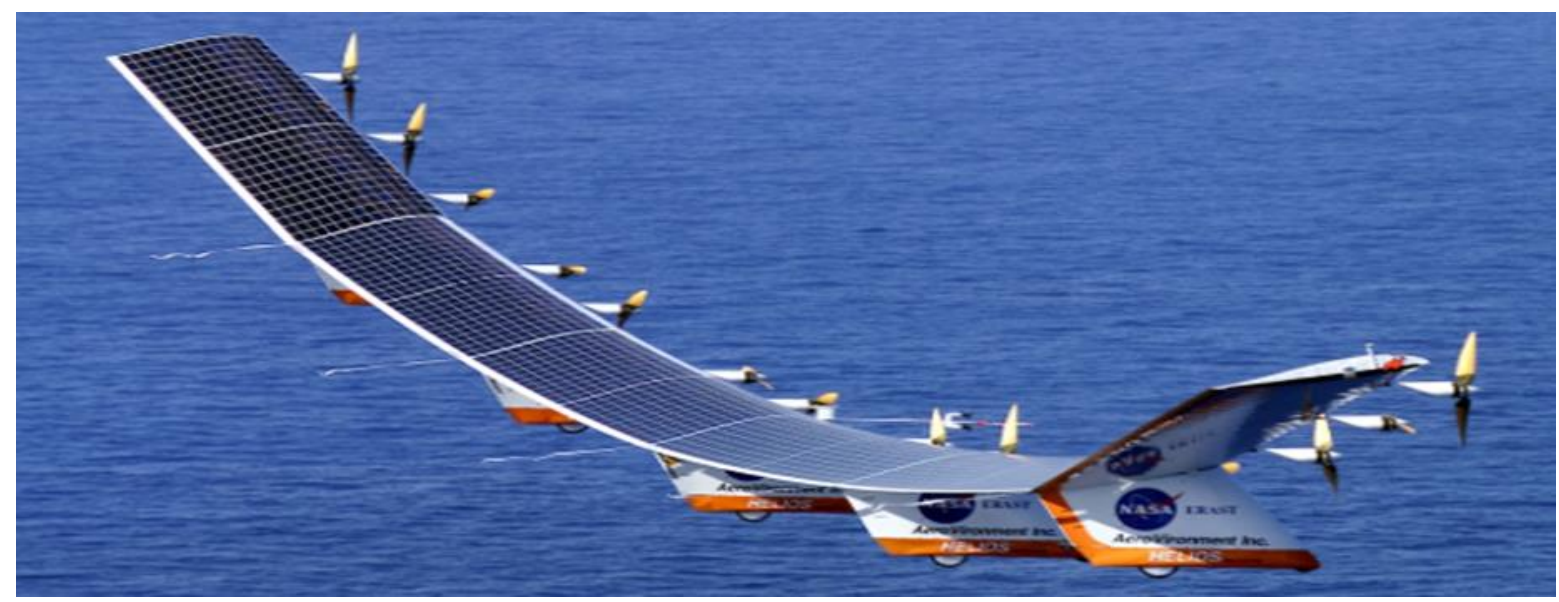

Fig. 6. NASA's helios solar aircraft

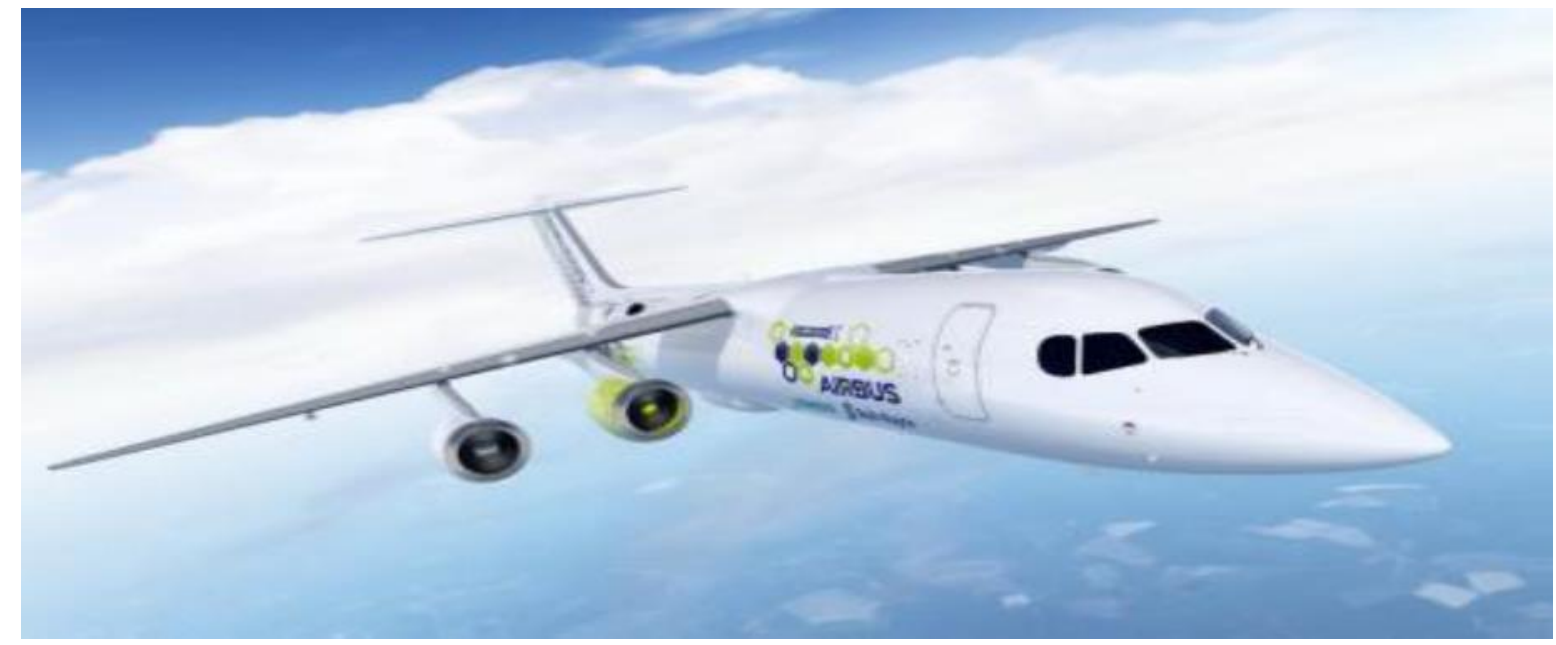

Fig. 7. E-Fan X technology by airbus

The long-term goal is to build a commercial aircraft equipped with E-Fan X technology, with a capacity of 50-100 passengers and capable of flying regional and short-haul routes, which is expected to enter service around 2035[19, 20].

\section{Conclusion}

The transition to renewable energy sources in general and in the aviation industry in particular is a positive step towards protecting the environment and slowing climate change. However, solar-powered airplanes have a long way to go before they can act as a complete alternative to fossil fuels. However, solar drones in its current and future predictive forms can still be useful in fields such as atmospheric research and communications. Plans to use electrically powered airplanes as a clean energy have made strong progress recently. Electric motors do not produce any emissions during their operation. Electric power generation is clearly not emission-free today, but the associated emissions have decreased significantly. This makes them a crucial element of technology in achieving environmental goals. Gas turbine engines are used for hybrid electric systems, propulsion generation and battery charging. In addition, the batteries provide the energy needed for propulsion during various phases of flight.

As a result, it is a fact that the use of solar energy, which is an alternative energy, in aircraft is very important in reducing fossil fuels as a result of both a clean nature and reducing aircraft engine noise.

\section{$\underline{\text { ORCID }}$}
R. Güntürkün
0000-0002-6755-7941
S. Çınar
0000-0003-0406-3079

\section{References}

[1] Bücür, Y., 2001, "Konutların Elektrik Enerjisi ihtiyacının Günes Enerjisi ile Sağlanması", Yüksek Lisans Tezi, Marmara Üniversitesi FBE istanbul.

[2] De Vos, A., "Endoreversible Thermodynamics of Solar Energy Conversion", Oxford University Pres, New York 1992.

[3] Korkmaz, A., 2001, "Günes Enerjisinden Direkt Elektrik Üretimi”, Yüksek Lisans Tezi YTÜ FBE, Istanbul. 
[4] Markvart T., 1994, Solar Electricity, J. Wiley and Sons, Chichester, UK.

[5] Ogulata, R.T., 2003, "Energy Sector and Wind Energy Potential in Turkey", Renewable

[6] Sustainable Energy, 7:468.

[7] Ültanır, M.Ö., 1996, “21yy. Esiginde Günes Enerjisi”, Bilim ve Teknik, 340:50-55

[8] Zhang Jin-hua, 2009. "Compute Analysis of the Capacity of PV System of Solar Energy", Gansu Science and Technology[J], 6, pp: 57-60

[9] Başol, B., Güntürkün, R., Başol, E., 2017. "Smart Home Design and Application", World Wide Journal of Multidisciplinary Research and Development, 3(6): 5358.

[10] Güntürkün, R., Kitiş,Ş., Apaydın,h., Mazlum,C.C., 2016," Heating Residences Using Solar Power", American Scientific Research Journal for Engineering, Technology, and Sciences (ASRJETS)) Volume 26, No 1, pp 1-7, ISSN (Print) 2313-4410.

[11] IEA. World Energy Outlook 2018, https://www.iea.org/weo/

[12] IATA Aircraft Technology Roadmap to 2050, s.29

[13] https://www.oxfordsaudia.com/en/blog/solar-poweredairplanes-the-history-and-future-of-solar-flights/

[14] http://air-e.nl/announcement/first-solar-poweredaircraft-mauro-solar-riser/

[15] https://www.havajet.com/bunlari-biliyormusunuz/solar-impulse/

[16] https://www.nasa.gov/centers/dryden/history/pastproje cts/Erast/pathfinder.html

[17] https://www.elektrikport.com/makale-detay/gunesenerjili-ucaklar/4417\#ad-image-0

[18] Airbus, Rolls-Royce, and Siemens team up for electric future Partnership launches E-Fan X hybrid-electric flight demonstrator,2017.

http://www.airbus.com/newsroom/pressreleases/en/2017/11/airbus--rolls-royce--and-siemensteam-up-for-electric-future-par.html\#media-list-imageimage-all_ml_0-2

[19] Kim, H.D., Brown, G.V., Felder, J.L. Distributed Turboelectric Propulsion for Hybrid Wing Body Aircraft. International Powered Lift Conference, London, July 2008. https://ntrs.nasa.gov/archive/nasa/casi.ntrs.nasa.gov/20 080021214.pdf

[20] NASA. Hybrid Electric Propulsion - Airplane Concepts, 2018. https://www1.grc.nasa.gov/aeronautics/hep/airplaneconcepts/ 